\title{
In Our Small Room, Imperceptibly
}

Swedenborg reports that, in a way of speaking, the act of passage is a matter of detail.

When he is no more, man is not conscious of his moment. He walks the streets and the riverbanks, his friends come to pay him a visit, they drink tea, banks and churches go on with their business, cats keep themselves warm in the sun, the army is in a state of alert. Tea tastes like tea, friends discuss football, the radio is on, parents complain what all this is leading up to. We imagine that the time

of the passage is shrouded in mist, because our senses die off, etc. Then there is also the possibility of death making them sharper. But it is not so. Imperceptibly, in our small room things take up a different shape. We see there is more colour to the world than we were used to taking notice of. Turning the high street the late night tram utters an indescribable sound; the language of humans and animals is transformed into unintelligible music; a muted conversation in the café is full of light.

Still we carry on as if nothing had happened. We keep up with our dates, with our musical recitals, with our Sunday outings to the lake; every so often we go to the movies or to the theatre. But we don't pick up phones, since the contents of the calls are known to us in advance; we read books in languages we 
never learned to speak; we notice the florist whom we have last seen in our childhood giving us a nod of recognition. There would be unposted letters and complete strangers arriving

at our doorstep, we would speak to them under the passageways, on the roof tops and terraces, in the suburbs, where, had it been otherwise, we would never have cared to venture. All this may go on for weeks, months, even years. By then one is made aware of who the callers were and what he himself has become; he makes ready for his moving away, takes leave of his friends and relatives, who seem strangely unbaffled by his decision. Then comes the day when he takes off in one of the Charon buses

and riding with a strange taste of copper in his mouth comes into a high valley of fens and gorges with big cities and towns, many of them devastated and charred as if consumed by fires. The sky is dark and deep with no stars and no sun. Soon, without realising how, he starts coming into an office, finds himself a job, recognising in his superiors the visitors of his unlikely conversations. His is a world of conspiring and hatred, fast decisions and summary injustice, where everybody gets promoted and nobody seems excessively

unhappy. A place of blooming opportunities and uninterrupted promotion. On one occasion he takes part in a secret meal where they are shown the world of the sun and the celestial 
bodies, which he rejects. Then, on another, they visit the park opposite the music school where he used to teach and where he now watches the undergraduates, entangled in the network of time, sitting on the grass, resonating like an old piano concerto he remembers from a long time ago. He declines any suggestion of return.

Translated from the Slovenian by the author 